\title{
An Improved Method for Acclimatizing Tissue-cultured Walnut Plantlets Using an Antitranspirant
}

\author{
Demetrios G. Voyiatzis ${ }^{1}$ and Gale H. McGranahan \\ Department of Pomology, University of California, Davis, CA 95616
}

Additional index words. Juglans regia

Plants grown in vitro usually do not possess protective mechanisms against desiccation. Impaired stomatal function (Marin et al., 1988) and reduced epicuticular waxes (Gaspar et al., 1987; Sutter, 1988) have been noted in these plants. In addition, their photosynthetic competence may be reduced (Preece and Sutter, 1991). When transferred to the greenhouse or the field, ex vitro plantlets are subjected to desiccation due to rapid water loss and may soon die. To minimize the effects of transplantation stress, the ex vitro plantlets should be hardened-off before being exposed to harsh field conditions.

Under standard acclimatization, plantlets are transferred from in vitro conditions to the greenhouse and are planted in a soilless mix in plastic "sweat boxes" or in flats inside plastic frames, where a microenvironment of high relative humidity $(\mathrm{RH})$, similar to that of the in vitro culture, is maintained by misting or fogging. The $\mathrm{RH}$ is then lowered progressively from $100 \%$ to that of the ambient environment until the plantlets have been hardened-off enough to be grown in a greenhouse and finally in the field.

Using substances that reduce transpiration rates by forming a semi-permeable membrane on the leaf surface recently has been reported for limiting water use by peach/Prunus persica (L.) Batsch] trees (Steinberg et al., 1990), for prolonging the salable life of red cedar (Juniperus virginiana L.) Christmas trees (Hinesley, 1990), and for protecting from diseases (Han, 1990). Attempts to reduce transpiration and to enhance survival rates of some in vitro-grown "flowers by covering the leaf surface with antitranspirants have not been successful (Sutter and Hutzell, 1984).
The purpose of this work was to investigate the possible use of latex polymer as an antitranspirant for acclimatizing micropropagated walnut plantlets.

In vitro-rooted microshoots of the walnut clone TRS with three to five leaves and 0.5-to 3-mm-long roots were used. The leafy part of each plantlet was dipped into an aqueous solution $(1: 20 \mathrm{v} / \mathrm{v})$ of the cross-linked carbon acrylic latex polymer Anti-Stress 550 (Polymer Ag, Fresno, Calif.). The plantlets were placed back in the culture vial, and after $24 \mathrm{~h}$, they were transplanted into a 1 peat: 1 vermiculite $(\mathrm{v} / \mathrm{v})$ mix in uncovered $250-\mathrm{ml}$ pots and placed in a greenhouse. The air ranged from $21 \mathrm{C}$ at night to $35 \mathrm{C}$ during the day, and $\mathrm{RH}$ ranged from $60 \%$ to $70 \%$. Nontreated controls were not included because, in preliminary trials, plantlets dipped in water and exposed to an open environment became dessicated and died within 6 to $8 \mathrm{~h}$. Similar plantlets were transferred to plastic boxes where RH was lowered by opening the lids gradually over 3 to 4 weeks. The fresh and dry weights of shoots and roots of sampled plants, the number of leaves, and the height of the plants were recorded at the beginning of the acclimatization period and after 30 days.

Latex dipping generally matched the standard method of acclimatization in producing hardened-off walnut plants. The average number of leaves per plant, plant height, and the size of the youngest fully developed leaf (top leaf) did not differ significantly between the two methods, but the survival rate of plants dipped in latex was higher than that of the controls (Table 1). Plantlets treated with latex accumulated significantly more dry matter, apparently because their newly formed leaves were able to photosynthesize under the favorable conditions of the open environment longer than the controls. In addition, because the antitranspirant protected against excessive transpiration (Steinberg et al., 1990), a water balance more favorable to growth was established inside the tissues of the treated plants, as the fresh weights showed.

Because phytotoxicity and impaired growth caused by antitranspirants may be encountered (Sutter and Hutzell, 1984), the effectiveness of such chemicals in acclimatization depends on the species, and, therefore, they must be used with caution. Our experiments indicated that the latex-dipping procedure is a simple, easily applied method that can be used for acclimatizing micropropagated walnut plantlets.

\section{Literature Cited}

Gaspar, T., C. Kevers, P. Debergh, L. Maene, M. Paques, and P. Boxus.1987.Vitrification: Morphological,physiologicalandecologicalaspects, p. 152-166. In: J.M. Bonga and D.J. Durzan (eds.).Cell and tissue culture in forestry. vol. 1. MartinusNijhoff, Dordrecht, The Netherlands.

Han, J.S. 1990. Use of antitranspirant epidermal coatingsforplant protection in China.PlantDis. 74:263-266.

Hinesley,L.E. 1990. Latex colorant slows drying of redcedar Christmastrees.HortScience 25:673674.

Marin, J. A., R. Gella, and M. Herrero. 1988. Stomatal structure and functioning as a response to environmental changes in acclimatized micropropagated Prunus cerasus L.Ann.Bet.62:663670.

Preece, J.E. and E.G. Sutter. 1991. Acclimatization of micropropagated plants to the greenhouse and field, p. 71-93. In: P.C. Debergh and R.H Zimmerman(eds.).Micropropagation. Kluwer Academic Publishers, Dordrecht, The Netherlands.

Steinberg, S. L., M.J. McFarland, and J.W Worthington. 1990. Antitranspirant reduces water use by peach trees following harvest. J. Amer. Soc. Hort. Sci. 115:2\&24.

Sutter, E. 1988. Stomatat and cuticular water loss from apple, cherry, and sweet-gum plants after removal from in vitro culture. J. Amer. Soc. Hort. Sci. 113:234-238.

Sutter, E.G. and M. Hutzell. 1984. Use of humidity tentsandantitranspirantsin the acclimatization of tissue-cultured plants to the greenhouse. Scientia Hort.23:303-312.
Received for publication 16 Dec. 1993. Accepted for publication 13 Aug. 1993. We thank Polymer $\mathrm{Ag}$, Fresno, Calif., for donating Anti-Stress 550 used in this study.Mention of a trade name does not imply endorsement of the product or the exclusion of others that maybesuitable.Thecost of publishing this paper was defrayed in part by the payment of page charges. Under postal regulations, this paper therefore must be hereby marked advertisement solely to indicate this fact.

'Visiting scholar(North Atlantic Treaty Organization). Current address: Dept. of Plant Production, Univ. of Thessaloniki, GR-540 06 Thessaloniki, Greece.
Table 1. Growth characteristics and survival rates of micropropagated walnut plantlets acclimatized 30 days without (control) and with latex antitranspirant application.

\begin{tabular}{lcc}
\hline \hline Criterion & Control & Latex \\
\hline No. of leaves & $3.5 \pm 0.3^{z}$ & $4.1 \pm 0.3^{2}$ \\
Plant height $(\mathrm{cm})$ & $1.3 \pm 0.2$ & $1.6 \pm 0.5$ \\
Length of top leaf $(\mathrm{cm})$ & $8.8 \pm 0.4$ & $7.7 \pm 0.6$ \\
Gain in fresh weight $(\%)^{y}$ & & \\
$\quad$ Shoots & $353 \pm 24$ & $505 \pm 30$ \\
$\quad$ Roots & $8 \pm 2$ & $13 \pm 3$ \\
Gain in dry weight $(\%)^{y}$ & $89 \pm 7$ & $685 \pm 38$ \\
$\quad$ Shoots & 0 & $65 \pm 4$ \\
$\quad$ Roots & $55.0 \pm 5.0$ & $66.5 \pm 4.5$ \\
Survival rate &
\end{tabular}

${ }^{\mathrm{z}}$ Values are means of 25 plants for the control and 50 plants for the latex treatment \pm SE.

${ }^{y}$ Gain in weight during the 30 -day acclimatization period. 